\title{
Condition of Forest Soils Under Plantations Of Scots Pine of Various Age in the Forest-Steppe Zone of Trans-Ural
}

\author{
Kulyasova Oksana \\ Department of Soil Science and Agrochemistry, \\ Federal State Budgetary Educational \\ Institution of Higher Education \\ «Northern Trans-Ural State Agricultural University» \\ Tyumen, Russia \\ soil-tyumen@yandex.ru
}

\begin{abstract}
The paper contains an analysis of fertility changes in dark gray forest soils under man-made forests of Pinus sylvestris (L.) with the age of $15 ; 30 ; 45$ and 60 years. The studies were performed in the territory of a forest enterprise located in Abatsky district of Tyumen oblast, in the northern forest-steppe of Western Siberia. Dark gray forest soil under a birch forest was used as a control. It has been established, that change in type of forest cover leads to changes in the species composition of the grass and shrub stratum. Humus state of the dark gray forest soils under man-made pine forests gradually deteriorates. Humus content reduces to $5.4 \%$ in the case where pines reach 60 years of age, while in the control plot under natural vegetation it amounts to $7.4 \%$ of soil mass. Qualitative composition of humus also gradually deteriorates: A fulvate-humate type is substituted with a humate-fulvate one, with low nitrogen enrichment. It has been established, that leaching is amplified under man-made pine forests with the age of under 45 years. Subsequently (60 years), podzolization starts in the dark gray forest soil, manifesting as destruction of soil adsorbing complex and increased acidity of the humus layer. In 45 years, base saturation decreased from $77 \%$ to $\mathbf{7 1 \%}$ of the cation exchange capacity. Change in the humus state and chemical properties had a negative impact onto agrophysical properties of the dark gray forest soil. Water stability of structural aggregates gradually reduces from 65 to $42 \%$ with increased age of pine, while bulk density increases to $1.27 \mathrm{~g} / \mathrm{cm} 3$. To prevent loss of fertility soils in Northern Trans-Ural, it is recommended to thoroughly analyze the plots planned under coniferous trees, to avoid their planting onto dark gray forest soils or soils similar in fertility. When moving such soils into arable lands, special measures are required for radical improvement in fertility (application of fertilizers, chalking) with subsequent sowing of perennial herbs.
\end{abstract}

Keywords - man-made coniferous forests; Scots pine; dark gray forest soil; fertility; humus state; degradation.

\section{INTRODUCTION}

The structure of the soil cover of northern forest-steppe in Western Siberia is complex and varies significantly depending on geomorphologic location $[1,2]$. All the drained territories are taken up largely by gray forest soils and chernozems in various combinations with meadow-chernozem soils.
Solodized kind prevails among the gray forest soils and leached subtype prevails among chernozems. All the flat plains of interfluves, as well as terraces of low geomorphologic levels are taken up by complex combinations and complexes of hydromorhic and saline soils. As the subzone of the northern, forest-steppe is the most favorable for intensive agricultural development for both climatic and soil conditions, almost all the soils with a high level of fertility are involved in agriculture. Currently, works are underway for finding new potentially fertile soils to involve them in agriculture [3]. The forestation level of the territory does not exceed $40 \%$; the forests are mostly birch and aspen massifs. Coniferous forests are located in small patches on podzolic soils, thus, development of forest industry in some municipal districts would require creation of man-made forests of valuable wood species. The most common species is Scots pine, which is easily acclimatized and quickly achieves necessary state of merchantable wood. In the northern foreststeppe, man-made coniferous forests are usually planted in the territories where birch and aspen forests were cleared and where gray forest soils have formed. This type is characterized with a wide range of fertility levels defining its use for human activities. Light gray and gray forest soils have no agricultural values, but the same cannot be said about the dark gray forest soil subtype. By their potential fertility, this subtype is on par with leached chernozems and may be actively employed under plow [4]. Thus, planting man-made forests of coniferous trees, in particular pine, may lead to decreased fertility and high material and technical costs for soil reclamation.

Research objective: analysis of fertility dynamics of the dark gray forest under pine plantations in Western Siberia.

\section{SUBJECTS AND METHODS}

The studies were conducted in the territory of Abatsky forestry enterprise, located in the northern forest-steppe of Trans-Ural, in the south of Tyumen oblast. Temporary testing areas were planted with Scots pine, which was planted along the plowed furrows $15 ; 30 ; 45$ and 60 years ago in the territory of cleared motley grass birch forests. Pine planting system: Inrow distance is $0.75-1.0 \mathrm{~m}$, distance between the rows is 2.5 - 
$3.0 \mathrm{~m}$. Control is primary motley grass birch forest, forest stand category 10B. Age of birch is 55 years; average height is $21-22 \mathrm{~m}$; stem diameter is $21.7 \mathrm{~cm}$; crown density is 65 $70 \%$. The following plants represent the grass and shrub cover: Calamagrostis arundinacea (L.); Calamagrostis epigejos (L.); Rubus saxatilis (L.); Fragaria vesca(L.); Pulmonaria obscura (Dumort.); Aegopodium podagraria (L.) [5].

The pine cultures of the 15 years of age are characterized with the following indicators: Average height is $8-9 \mathrm{~m}$. Average stem diameter (at $1.3 \mathrm{~m}$ ) is $10.5 \mathrm{~cm}$. Crown density is $20-25 \%$. Dominants in the grass and shrub cover: Calamagrostis arundinacea (L.); Calamagrostis epigejos (L.); Elytrigia repens (L.); Alopecurus pratensis (L.); Agrostis gigantea (RoTH.); Poa angustifolia (L.). Cultures of the 30year-old pine. Average height is $15-16 \mathrm{~m}$. Average stem diameter is $15.8 \mathrm{~cm}$. Crown density is $75-80 \%$. Dominants in the grass and shrub cover: Calamagrostis arundinacea (L.); Calamagrostis epigejos (L.); Rubus saxatilis (L.); Fragaria vesca (L.); Poa angustifolia (L.); Orthilia secunda(L.); Pyrola rotundifolia (L.).

For the plots planted 45 years ago: Average height is 20-21 $\mathrm{m}$. Average stem diameter is $20.4 \mathrm{~cm}$. Crown density is $70-$ $75 \%$. Grass cover dominants are Rubus saxatilis(L.), Fragaria vesca(L.); Poa angustifolia(L.); Calamagrostis arundinacea (L.); Calamagrostis epigejos (L.); Orthilia secunda (L.); Pyrola rotundifolia (L.); Chimaphila umbellata (L.).

Cultures of the 60 -years-old pine. Average height is 24-25 $\mathrm{m}$. Average stem diameter (at $1.3 \mathrm{~m}$ ) is $24.6 \mathrm{~cm}$. Crown density is $65-70 \%$. Grass cover dominants are Orthilia secunda (L.), Pyrola rotundifolia (L.) Chimaphila umbellata (L.);Rubus saxatilis (L.); Fragaria vesca(L.), Polygonatum odoratum (MILL.).

The soil in the studied plots is a dark gray forest soil, medium loamy with the characteristics typical of the northern forest-steppe of Western Siberia. Table 1 contains a description of a soil profile taken as a reference. The cut was made in the territory where man-made forests of Scots pine of various age were planted.

The full-scale cut was made in the similar element of relief, and, as the description of its morphological attributes shows, identical soil-forming rock. It gave an ability to study the soil formation process when the edifying forest stand changes and determine the influence of various period of growth of the pine plantations on fertility of the dark gray forest soils. The cut description was made by the author jointly with employees of Department of Soil Science and Agrochemistry of the Northern Trans-Ural State Agricultural University.
TABLE I. DESCRIPTION OF SOIL PROFILE OF A DARK GRAY FOREST SOIL (BIRCH FOREST)

\begin{tabular}{|l|l|}
\hline \multicolumn{1}{|c|}{$\begin{array}{c}\text { Horizon, } \\
\text { depth, cm }\end{array}$} & \multicolumn{1}{c|}{ Morphological attributes } \\
\hline A0 0-2 & Radicular grassy turf, leaf litter \\
\hline A1 2-27 & $\begin{array}{l}\text { Dark gray, moist, medium loamy, granular-cloddy, } \\
\text { lightly compacted, lots of roots. Gradual transition. }\end{array}$ \\
\hline B1 27-36 & $\begin{array}{l}\text { Brown gray, moist, heavy loamy, dense, lumpy-powder- } \\
\text { like, lots of roots. Gradual transition. }\end{array}$ \\
\hline B2 36-67 & $\begin{array}{l}\text { Brown, watered, heavy loamy, nutty-cloddy, dense, fine } \\
\text { porous, roots. Gradual transition. }\end{array}$ \\
\hline B3 67-120 & $\begin{array}{l}\text { Brown, fresh, heavy loamy, nutty, dense, fine porous, } \\
\text { roots. Gradual transition, transition by carbonate } \\
\text { presence is clear. }\end{array}$ \\
\hline Bк 120-170 & $\begin{array}{l}\text { Light brown, fresh, medium loamy, instable-nutty, fine } \\
\text { porous, compacted, single roots, boils in HCI, } \\
\text { carbonates in the form of veinlets and hard } \\
\text { agglomerations. }\end{array}$ \\
\hline C $>170$ & $\begin{array}{l}\text { Yellow straw, fresh, medium loamy, non-structured, fine } \\
\text { porous, compacted, boils in HCI. }\end{array}$ \\
\hline
\end{tabular}

Nutrient content was determined in the agrochemical laboratory of the university, with the following methods: Nitrate nitrogen by disulfophenol method; labile forms of phosphorus and potassium by Chirikov's method. Exchange acidity was determined by a potentiometric method; total sum of exchange bases and hydrolytic acidity was determined following the Guidelines for Chemical Analysis of Soils. Bulk density and water stability was determined by Kachinsky's method. Statistic processing of the results was performed according to the method of B.A. Dospekhov, using Microsoft Excel.

\section{RESULTS}

Effective fertility of the dark gray forest soils is virtually the same as that of virgin chernozems of Northern Trans-Ural. It should be noted, that there is a common feature between them, namely, instable nitrogen mode, both in the virgin state and under plow [6]. Our studies have shown, that nitrate content in humus-eluvial layer of the control plot (birch forest) is $5.8 \mathrm{mg} / \mathrm{kg}$, corresponding to a very low availability of this nutrient (Table 2). By the middle of summer, nitrate nitrogen content may increase due to activity of soil microbial population and a large number of plant residues in the form of roots of herbaceous plants. Anthropogenic replacement of the birch forests with planted pine cultures impaired the nitrogen status of the dark gray forest soils. Nitrate content decreases with the age of pine, reaching its minimum after 30 year at 4.2 $\mathrm{mg} / \mathrm{kg}$ of soil. In more aged pine forests, nitrate nitrogen content never exceeded $4.0 \mathrm{mg} / \mathrm{kg}$. The cause of this phenomenon lies in the change of species composition of the grass and shrub cover and manifestation of soluble nitrogen leaching down the profile [7]. 
TABLE II. DYNAMICS OF NUTRIENT CONTENTS IN DARK-GREY FOREST SOIL UNDER PLANTATIONS OF SCOTS PINE, MG/KG

\begin{tabular}{|c|c|c|c|c|c|}
\hline \multirow{2}{*}{ Indicators } & \multirow{2}{*}{$\begin{array}{c}\text { Control } \\
\text { (birch } \\
\text { forest) }\end{array}$} & \multicolumn{4}{|c|}{ Age of pine culture } \\
\hline & & 15 & 30 & 45 & 60 \\
\hline Nitrate nitrogen & 5.8 & 4.5 & 4.2 & 4.0 & 4.0 \\
\hline Labile phosphorus & 68 & 56 & 55 & 40 & 40 \\
\hline Labile potassium & 180 & 170 & 130 & 120 & 120 \\
\hline
\end{tabular}

By the mobile phosphate content, the dark gray forest soils of Northern Trans-Ural are of medium availability. Only when they are involved in agriculture and undergo systematic application of phosphoric fertilizers, phosphorus availability increases to an enhanced or high level [8]. Content of labile phosphorus in the humus layer of dark gray forest soil under the birch forest is $68 \mathrm{mg} / \mathrm{kg}$, which is within the range for virgin chernozem $(45-80 \mathrm{mg} / \mathrm{kg})$. Under plantations of $15-$ years-old pines the phosphate content is $18 \%$ lower than in the control plot. Under more aged plantations, this indicator reached minimum values at $40 \mathrm{mg} / \mathrm{kg}$, corresponding to very low plant availability of phosphorus. Biogenic removal cannot be the only cause of this phenomenon, as pine consumes significantly less phosphorus than deciduous trees, and grass cover in the pine plantations is significantly weaker than in the birch forest. Thus, there is a hypothesis of a possible manifestation of phosphorus migration deeper through the profile. It is facilitated by increased wet depth under the pine forests and a soil acidification effect due to chemical composition of decomposing plant residues.

Northern Trans-Ural has a specific content of soil-forming rocks, one of the main feature is initial high content of total potassium. It has a favorable effect on potassium status of modern soils in this territory. As the gray forest soil type in the Northern Trans-Ural is represented mostly by granulometrically heavy subtypes, the natural content of labile potassium is in the range from 150 to $200 \mathrm{mg} / \mathrm{kg}$. In the control plot (birch forest), the content of this nutrient was 180 $\mathrm{mg} / \mathrm{kg}$, which is sufficient not only for crops, but for woody plants as well. Plantations of Scots pine created 15 years ago in the place of a cleared birch forest did not affect the potassium status of the dark gray forest soil; the deviations were within the boundaries of a measurement error. However, in the plots where the age of pine culture reached 30 years, potassium content dropped to $130 \mathrm{mg} / \mathrm{kg}$, the deviation with respect to the birch forest is $28 \%$, which is considered a rapid deterioration in the potassium status. Plant-available forms of potassium are primarily concentrated in the soil absorbing complex, driven by humus substances and silty mineral particles. It is a common opinion that coniferous trees as they grow start depressing herbaceous vegetation, thus deteriorating humus formation in the soil, while accumulation of a large snow mass and almost total lack of water evaporation leads to migration of silty particles deeper through the profile (illuviation). The total result of these processes causes deterioration of the potassium status of the forest soils.
Humus status of soils is an essential element of fertility. Dark gray forest soils of Northern Trans-Urals almost match leached chernozems (the best soils in the region) in humus content and reserves [9]. Humus content values under the birch forest amounted to $7.3 \%$ of the soil weight, which corresponds to $260 \mathrm{t} / \mathrm{ha}$ (Table 3). Besides quantitative characteristic, qualitative content of soil organics is very important. In the first place, it is the ration between humic acids (HA) and fulvic acids (FA). By its composition, humus in the control plot corresponds to a fulvate-humate type (1.3), characteristic of gray forest soils of Northern Trans-Urals. Humus enrichment with nitrogen corresponds to an average level $(\mathrm{C}: \mathrm{N}=9)$. This fact indicates a rather favorable nitrogen potential of the dark gray forest soil, making it agriculturally valuable. Use of such soils under plow makes it possible to obtain high yields of grains with application of relatively low dosage of mineral fertilizers.

During the first 15 years, change in forest cover did not result in reduced humus content, the deviations were within the margin of measurement error $(0.4 \%)$. However, the qualitative composition started to change, HA to FA ratio dropped by $15 \%$ and reached 1.1 . The type of humus remained the same (fulvate-humate), but the deteriorating trend is evident. It is also clearly seen in analysis of availability of nitrogen in organics: $\mathrm{C}: \mathrm{N}$ ratio increased to 10 . Under plantations of Scots pine of 30 years age, humus content reached $6.2 \%$ of the soil weight.

TABLE III. CHANGES IN HUMUS STATUS AND CHEMICAL PROPERTIES OF DARK GRAY SOILS UNDER PLANTATIONS OF SCOTS PINE

\begin{tabular}{|c|c|c|c|c|c|}
\hline \multirow{2}{*}{ Indicators } & \multirow{2}{*}{$\begin{array}{l}\text { Control } \\
\text { (birch } \\
\text { forest) }\end{array}$} & \multicolumn{4}{|c|}{ Age of pine culture } \\
\hline & & 15 & 30 & 45 & 60 \\
\hline $\begin{array}{l}\text { The content of humus in } \\
\text { the A1 horizon, } \%\end{array}$ & 7.3 & 7.0 & 6.2 & 6.3 & 5.4 \\
\hline $\begin{array}{l}\text { Ratio of humic to fulvic } \\
\text { acids }\end{array}$ & 1.3 & 1.1 & 1.1 & 0.8 & 0.7 \\
\hline $\begin{array}{l}\text { Enrichment of humus } \\
\text { with nitrogen }(\mathrm{C}: \mathrm{N})\end{array}$ & 9 & 10 & 10 & 12 & 12 \\
\hline exchange acidity, un & 5.9 & 5.7 & 5.5 & 5.5 & 5.2 \\
\hline $\begin{array}{l}\text { Amount of exchange } \\
\text { cations, mg-eq } / 100 \mathrm{~g} \text { of } \\
\text { soil }\end{array}$ & 22.5 & 21.4 & 20.3 & 18.2 & 17.6 \\
\hline $\begin{array}{l}\text { Hydrolytic acidity, mg- } \\
\text { eq/100 g }\end{array}$ & 6.7 & 6.8 & 7.7 & 7.5 & 7.5 \\
\hline $\begin{array}{l}\text { Cation } \quad \text { exchange } \\
\text { capacity, mg-eq/100 g }\end{array}$ & 29.2 & 28.2 & 28.0 & 25.7 & 25.1 \\
\hline $\begin{array}{l}\text { The degree of saturation } \\
\text { with cations, } \% \text { of the } \\
\text { cation } \\
\text { capacity }\end{array}$ & 77 & 76 & 73 & 71 & 70 \\
\hline
\end{tabular}

Further increase in age (45 years) did not have reliable effect on the humus content: the values did not differ from those obtained for the 30-years-old pines. However, 45 years may be considered a boundary for serious changes in quality of soil organics. First, the humus type moved to humatefulvate (HA:FA=0.8), which is characteristic of light gray forest soil subtype and soddy podzolic soils of Northern Trans-Urals. Humus started quickly losing nitrogen: the C:N indicator amounted to 12 units, corresponding to low 
availability. Under pine plantations of 60 years there have been both qualitative and quantitative changes registered. The humus content in the upper level amounted to $5.4 \% \mathrm{wt}$, approximately, the loss amounted to $25 \%(65 \mathrm{t} / \mathrm{ha})$ with respect to the virgin dark gray forest soil.

HA:FA ratio reached the value of 0.7 , which is considered an unfavorable value for hyperhumus soils. Value of such humus sharply decreased, as its nitrogen availability corresponds to a low level. Involvement of such soils into agriculture would require significant expenses for fertility optimization.

Changes in the humus status under the pine cultures of over 30 years are visually noticeable. They appear as deterioration in structural and aggregate composition of humus horizon, which is represented by its cloddy-nutty type. In addition, natural dark gray, almost black coloration changed into light gray and gray ones. As the humus status have a strong influence over structural formation, virtually all fertility elements (agrophysical, physical, chemical, hydrophysical properties and biological status) will further deteriorate with development of coniferous trees.

Dark gray forest soils of Northern Trans-Urals have an optimal acid-base characteristic. This is due to a vicinity of the illuvial carbonate horizon, which impedes natural acidification of soils. Exchange acidity in the birch forest plot was at the level of 5.9 units, corresponding to slightly acidic reaction. 15 years of growth of Scots pine did not have reliable effect on acidity of the dark gray forest soil; the deviations were within the margin of error. However, the acidification process was detected under the older plantation of Scots pine. There is a strong positive correlation between the age of pine and exchange acidity, correlation coefficient is 0.94 . Under the plantations of Scots pine with the age of 60 years the exchange acidity reached the value of 5.2 units, corresponding to a serious acidification of soil and start of its chemical degradation. The stable acidification of the dark green forest soil under man-made pine forests of various age is caused by a complex of factors. Change in the chemical composition of plant residue leads to formation of humic molecules having low molecular mass and pronounced acidic properties. As the pine forest grows, there are simultaneously a growth in winter snowpack and a reduction of evaporation, while underdeveloped grass vegetation is no longer able to form a desuctive-exudative water regime where carbonates ascend to the humus horizon. Such acidification mechanism was previously registered in plowed chernozerms by the Department of Soil Science and Agrochemistry of the North Trans-Urals State Agricultural University and described in detail in their publications, see [10].

Primary changes in the chemical properties of the soil cannot be registered visually. Reflection of the chemical degradation in the morphological properties of soil horizons takes place only when the process continues for a prolonged period of time and at a stage where it can no longer be prevented. Thus, monitoring would require regular chemical analysis [11]. The most important indicator is the cation exchange capacity, which includes the total of exchange bases and hydrolytic acidity. In the virgin dark gray forest soil, the cation exchange capacity amounted to $29.2 \mathrm{mg}$-eq/100 g of soil. The main part falls to the share of exchange bases -22.5 $\mathrm{mg}-\mathrm{eq} / 100 \mathrm{~g}$ of soil. The degree of base saturation does not reach the values characteristic of leached chernozems and amounts to $77 \%$ of the cation exchange capacity.

Under 15-years-old plantations of Scots pine, the authors detected no reliable deviations in the chemical composition, the deviations were within the limits of the least significant difference. Under older pine forests (30 years) we detected an increased leaching of alkali earths $(\mathrm{Ca}$ and $\mathrm{Mg})$ from the soil absorbing complex. It is proven with a decrease in the total of exchange bases (20.3 mg-eq/100 $\mathrm{g}$ of soil) against the background of stable cation exchange capacity. This process is not a serious deviation, as it appears to a degree in all the soils of forest-steppe and taiga-forest zones [12, 13, 14]. In the soils under the 45- and 60-year-old pines, an attribute of the chemical degradation has been found: cation exchange capacity decreased to 25.7 and $25.1 \mathrm{mg}$-eq/100 g of soil respectively. It should be noted, that this deterioration changes along with the humus status.

It has been established, that the capacity of dark gray forest soils under pines of various age gradually decreases, reaching the minimum values of $70 \%$ of the cation exchange capacity. It makes it possible to state, that the acidification and podzolization processes manifest in full scale under the plantations of Scots pine after 30 years. Taking into account that dark gray forest soils are considered potentially fertile and are a prospective stock of agricultural land, appearance of chemical degradation and podzolization is very unacceptable.

Initially, dark gray forest soils of Wester Siberia have generally favorable agrophysical properties: well-pronounced water stability, crumbly structure, optimal bulk density and porosity [15]. These properties depend on the humus status of soils, thus, its deterioration impacts negatively first structural formation and then the other indicators as well. Morphological analysis of soil cuts have shown that the structure of humus horizon differs between the dark gray soils under plots with planted Scots pine of various ages and under the birch forest. Granular-cloddy structure of the birch plot is replaced with a cloddy-nutty structure. The qualitative indicator of structure is water stability. In the control plot, it is $65 \%$ of the total number of aggregates (Fig 1). In the plot with 15-year-old pines the water stability of aggregated did not differ from control. However, in plots covered with 30 -year-old pined this indicator reduced to $47 \%$, which is an evidence of a deteriorated structural formation. A trend for reduced water stability, and thus deterioration of other agrophysical properties of the dark gray forest soil under plantation of Scots pine is positively tracked. Its reality is supported with the water stability of $42 \%$ under the pines whose age reached 60 years.

Equilibrium bulk density of the humus layer of the dark gray forest soil at the control plot corresponded to the optimal value, $1.12 \mathrm{~g} / \mathrm{cm}^{3}$, making it similar to chernozems of TransUrals. After 15 years of pine growth, this indicator experienced insignificant increase to $1.20 \mathrm{~g} / \mathrm{cm}^{3}$. As the age of the forest stand increases, the trend for compression of the upper horizon continued, reaching maximum values under the 
60-years-old plantations. This fact is explained by deterioration of structural and aggregate composition and reduced root mass of grasses and shrubs. Formation of periodic non-percolative, and in some areas percolative water regime also has a compressing effect on the humus-eluvial horizon.

\section{CONCLUSION}

As a result of a detailed study of the dark gray forest soil into which Scots pine was planted at various times, it has been established, that soil fertility starts changing after 15 years of pine growth. Humus status of the dark gray forest soils under 45-years-old pine plantations undergo both qualitative and quantitative deterioration. It has a negative impact on agrophysical and agrochemical properties of the dark gray forest soil. Perennial plantations of coniferous cultures on potentially fertile soils lead to a serious change in the soil formation process, manifesting in the following stages: change of vegetation;'change in humus formation; increased leaching; destruction of soil-absorbing complex; increase in acidity of humus horizon. In plots where pines achieved 60 years of age, podzolic process of soil formation starts, manifesting in destruction of humus substances and mineral components of the soil, with subsequent illuviation of detrital products deeper through the soil. The upper part of the humus-eluvial horizon acquires visual attributes of podzolization: appearance of silicon earth powdering, gray coloration of the horizon. To prevent loss of fertile soils in Northern Trans-Ural, it is recommended to thoroughly analyze the plots planned under coniferous trees, to avoid their planting onto dark gray forest soils or soils of similar fertility. When moving such soils into arable lands, special measures are required for radical improvement in fertility (application of fertilizers, chalking) with subsequent sowing of perennial herbs.

\section{References}

[1] D.I. Eremin, "Soils swelling as a regional feature of Western Siberia," MATEC [Web of Conferences, 170, pp. 02017 https://doi.org/10.1051/matecconf/201817002017]
[2] D.I. Eremin, "The use of modern data about the composition and properties of soil for the development of transport infrastructure of Tyumen", [IOP Conference Series: Earth and Environmental Science, 2017, vol. 90, Conf. 1. DOI: org/10.1088/1755-1315/90/1/012021].

[3] D. Eremina, "IT-technologies in soil Informatics and Russian agribusiness", [MATEC Web of Conferences, 170, 2018, pp. 04016 DOI: https://doi.org/10.1051/matecconf/201817004016]

[4] D.I. Eremin and N. A. Gruzdeva, "Influence of anthropogenic factor on microaggregate composition of gray forest soils", Siberian Bulletin of agricultural science, 1,2018 , pp. 28-37. DOI: $10.26898 / 0370-8799-$ 2018-1-4

[5] M.R. Waters, S.L. Forman and J.M. Pierson, "Diring Yuriakh: A Lower Paleolithic Site in Central Siberia," Science, 275, 1997, vol. 275.

[6] S.G. Kotchenko, N.A. Gruzdeva and D.I. Eremin, "Dynamics of the content of different forms of nitrogen in arable grey forest soils of Northern Zauralye", 4, 2017, pp. 39-43.

[7] B.E. Chizhov, A.M. Shishkin and O.A. Kulyasova, "Succession of living ground cover in Scots pine crops, created on the felling of mixed birch forest-steppe of Western Siberia", Bulletin of the Altai state agrarian University, 3, 2016, pp. 96-102.

[8] N.A. Gruzdeva and D.I. Eremin, "Phosphate regime of arable gray forest soils of Northern Urals", Agrochemical Bulletin, 5, 2017, pp. 12-15

[9] D.I. Eremin, "Changes in the content and quality of humus in leached chernozems of the Trans-Ural forest-steppe zone under the impact of their agricultural use," Eurasian soil science, 2016, 5, pp. 538-545. DOI: $10.1134 /$ S1064229316050033

[10] N.V. Abramov, S.V. Abramova and D.I. Eremin, "The dynamics of acidity of leached Chernozem with different periods of use of the arable land", Bulletin of the Tyumen state agricultural Academy, 1, 2008, pp. 9-12.

[11] A.V. Iglovikov, "The development of artificial Phytocenosis in Environmental Construction in the far North", Procedia Engineering, 165, 2016, pp. 800-805. DOI:10.1016/j.proeng.2016.11.778.

[12] C.M. Monreal and H.H. Jansen, "Soil organic carbon dynamics after 80 years of cropping a dark brown chernozem", Canad. J. Soil Sci. 73, 1993, pp.133-136.

[13] A.A. Gol'eva, "Biomorph Analysis as a Component of the Genetic and Morphological Study of Soil", Eurasian Soil Science, vol. 9, 1997, pp. 927-936.

[14] O.A. Sorokina, "Diagnostic parameters of soil formation in gray forest soils of abandoned fields overgrowing with pine forests in the middle reaches of the Angara River", Eurasian Soil Science, 8, 2010, pp. 867875.

[15] N.V. Perfiliev and O.A. Musina, "Parameters of dark-grey forest soil at long application of various systems of the basic processing", Agriculture, 2, 2016, pp. 23-25. 